\title{
1. Introduction to Personal Sustainability Practices
}

\section{Mark Starik and Patricia Kanashiro ${ }^{1}$}

Welcome to our volume Personal Sustainability Practices: Faculty Approaches to Walking the Sustainability Talk and Living the UN SDGs! We are excited about this topic because it is a subject with which we co-editors as well as our authors and readers, has likely wrestled more than once in our respective careers as sustainability educators: "Are we walking our sustainability talk? Are enough of those of us who are faculty members practicing what we preach as frequently, substantively, and effectively as we should on the topic of sustainability?" Additionally, and importantly: "Are we making those practices as visible and salient as they deserve and need to be?" This volume addresses these weighty questions in the hope that readers ask themselves and their stakeholders those same questions, and, if the answer is that more personal sustainability action is required (Kanashiro, Rands, \& Starik, 2020; Parodi \& Tamm, 2019), then, let's all get to it!

\section{WHY WE INITIATED THIS EXPLORATION}

Several decades ago, as a graduate student at a prominent U.S. university, one of the co-editors of this volume, was listening to his Energy Policy master's course instructor in class discussing a number of academic and professional energy events that the instructor either had attended or soon would be attending. This distinguished, well-respected scholar, who had written several energy policy books, listed perhaps a half-dozen or more such events, some of which included him as a featured speaker on various aspects of energy sustainability, and all of which were strewn widely around the world, requiring dozens of airline flights, tens of thousands of miles of air travel, and many tons of $\mathrm{CO}_{2}$ emissions, the main greenhouse gas responsible for our global climate crises. The student thought to himself and would later discuss with a fellow student in the class whether or not their energy-conscious professor should be, as one of them described it, "flying all around the world, trying to save it," and whether we too, if we had the opportunity, would do the same. Several hundred flights and multiple decades later, that student, now a faculty member, 
and co-editor of this volume, is still asking himself that same vexing question, as well as many others, related to sustainability consistency. Cumulatively, he has flown "around the world" several dozen times, either for business or for pleasure, which he has finally, after several decades, stopped (except for emergencies). Some of us may have answered the above sustainability question in the negative, choosing to fly only when absolutely necessary. Apparently, and thankfully, many academics and others are also asking themselves similar consistency questions in the present day (Ciers, Mandic, Toth, \& Veld, 2019). Others have justified their flights (and other problematic unsustainable behaviors) in one manner or another and/or have purchased carbon offsets. Still others have likely decided to either stop or keep asking that and related questions and may never answer them. Given that the average Chicago-to-Frankfurt roundtrip flight (before electric or biofuel technologies become widespread) generates 2.3 tons of $\mathrm{CO}_{2}$ (myclimate, 2020) or more than one-tenth the average American's or one-fifth the average European's annual carbon footprint, that is a significant outsized carbon impact for a single flight. Of course, in addition to airline flights, this co-editor has also himself practiced and witnessed in some of his own and his former sustainability professors' and current sustainability colleagues' behaviors that might charitably be described as "questionable" from a sustainability perspective. Such behaviors have included owning and operating one or more very large vehicles, including sport utility vehicles, recreational vehicles, and motorized boats, and living in one or more very large homes significant distances away from our or their respective universities or other work locations. On the other hand, we, they, and others, may have lived in solar (active or passive) or otherwise energy-efficient homes, driven small electric automobiles or used alternative forms of transportation, and/or have assisted in setting up and running local food banks or other community-oriented activities, among many other laudable (and sustainability-oriented) actions.

The flying question was one seed among many others that relate to the same general question about becoming and being a sustainability academic: To what extent and how should faculty members, especially those who verbally promote sustainability values in their teaching and research, put those values into practice and communicate with their stakeholders about both those values and those practices? As mentioned above, none of us is always consistent in "practicing what we preach," whether on sustainability or any other topic. However, the normative nature of sustainability and its implicit question, "How should we live, both environmentally and socio-economically, for the benefit of current and future generations and the rest of the planet?" seems to have embedded the need for sustainability faculty to be active generally, if not consistently, on several levels of sustainability (Starik \& Kanashiro, 2020). 
So, let's stipulate that none of us is perfect, whether we are teachers, researchers, practitioners, students, or any of the dozens of other roles we play in society throughout our lives. We, the co-editors, were not seeking perfection in this volume's chapters (we like the saying, "Progress not perfection"), but we did want to illuminate faculty personal sustainability practices and advance accountability regarding those practices. Most of us would likely agree that, if at all possible, teachers should generally practice what they preach (Bergart \& Simon, 2004), but since many of us are aspirational, we should also expect that we will probably not practice everything we preach all the time. However, shouldn't that fact be admitted and each of us be open and accountable for the gap between what we teach, research, or otherwise espouse, on the one hand, and what we really practice, on the other (Ruff, 2019)? This consistency between faculty teachings and faculty practice is sometimes termed congruency (Swennen, Lunenberg, \& Korthagen, 2008), and a number of suggestions have been forwarded to advance teacher congruency, with some of those described in this chapter and book. For example, teachers who actively engage with their students and who believe that learning can be generated from both past successes and past failures can share both of these sets of experiences with their students (Mihai, 2014), so that students not only learn these sustainability lessons, but are more motivated to put them substantively into practice in their own lives and careers.

\section{SUSTAINABILITY CHALLENGES AND OPPORTUNITIES IN OUR TIME}

Questioning one's own consistency is one way to explore the sustainability preaching-practicing dichotomy, but another is to pay attention to and possibly emulate others who have apparently resolved, at least in part, that dilemma successfully over time. In one co-editor's case, numerous and sometimes well-known authors, activists, and teachers helped influence and inform this sustainability consistency exercise, including (in alphabetical order by last name): T.C. Boyle, Lester Brown, Robert Bullard, Archie B. Carroll, Cesar Chavez, Arthur C. Clarke, Barry Commoner, Walter H. Corson, Jared Diamond, Paul Ehrlich, John Kenneth Galbraith, Bill Gates, Mahatma Ghandi, Jane Goodall, Al Gore, Asterios G. Kefalas, John Kerry, Ken Keyes, Jr., Martin Luther King, Naomi Klein, Winona LaDuke, Frances Moore Lappe, Annie Leonard, Amory Lovins, Wangari Maathai, Donella H. Meadows, Bill McKibben, Chico Mendez, George Monbiot, Barrie Pittock, Robert Redford, Kim Stanley Robinson, Carl Sagan, Paul Shrivastava, David Suzuki, Jessica Yinka Thomas, Studs Terkel, Neil de Grasse Tyson, Kurt Vonnegut, and Ken Saro Wiwa, among many others. Additionally, three visual but distant examples decades apart were especially both salient and serendipitous for this 
co-editor's involvement in this project. The first was his accidental stumbling onto a YouTube video featuring Dr. Peter Kalmus, and subsequently purchasing and viewing the video entitled Being the Change: A New Kind of Climate Documentary (Grandelis \& Davis, 2018), which tells the story of a N.A.S.A. atmospheric scientist (Dr. Kalmus) who not only addressed the climate crisis at work but also reorganized his and his family's personal lives to take whatever climate and sustainability actions they could at that level, including using biodiesel made from recycled restaurant cooking oil in his aging family car, beekeeping, gardening, bicycling, meditating, deciding with his wife to limit their family size, and actively participating in the Citizens' Climate Lobby and his local community climate projects. The second set of actors who appeared to be walking their sustainability talk (and then some) were Los Angeles (Studio City) neighbors Ed Begley, Jr. (whom the co-editor met at a Washington, D.C. sustainability conference) and Dr. Bill Nye (yes, "the Science Guy"), each of whom had their own sustainability-related television shows in the U.S. a few years ago and whose modest abodes were located in the same L.A. neighborhood. On several episodes of Begley's show called "Living with Ed," they engaged in a friendly competition over which one of their homes was more sustainable. While who won the competition was not important, what was important and impressive was their mutually amiable sustainability contest and their skill, imagination, and determination in installing the materials that were highly energy efficient, water efficient, and non-toxic, at reasonable cost in time and money (Schwartz, 2008). Yet a third positive inspiration in consistent sustainability for this co-editor is Dr. Doug McKenzie-Mohr, who developed the concept of Community-Based Social Marketing, which argues for the use of social psychology strategies, such as prompts, commitments, pilot testing, community orientations, and evaluation, to foster-that is, disseminate - sustainable behaviors related to agriculture, energy, transportation, waste, and water. In his work, he uses his own personal, household, and community examples, such as whether to compost in the Canadian winter and which of several transportation modes he chooses to get to work, to illustrate this sustainability diffusion, and does so through books (McKenzie-Mohr, 2011), conference speaking, online and in-person workshops (attended by this co-editor), and a website (cbsm.com) with hundreds of examples of his approach. Kalmus, Begley, Jr., Nye, and McKenzie-Mohr, each a "public educator" in his own way, were inspiringly consistent in their personal and professional sustainability behaviors and provided much-needed multi-decade boosts to this co-editor's efforts to follow, as much as possible, their inspiring "walking the talk" real-world examples.

Continuing on the subject of sustainability challenges and opportunities, one can imagine that a collection of chapters on the topic of faculty personal sustainability would likely include a wide diversity of subtopics and themes, 
and, at least on this point, the volume you are reading will likely not disappoint. Some of that diversity was by design, as the co-editors ensured that the call for proposal submissions included multiple possible subjects related to both environmental and socio-economic sustainability and to the several academic functions of research, teaching, and service, as well as the rest of our lives. We also wanted to ensure that faculty and other scholars and practitioners associated with any of a number of divisions and interest groups within several academic associations representing numerous world geographic regions, especially the Academy of Management's Organizations and the Natural Environment (O.N.E.) and Social Issues in Management (S.I.M.) divisions, knew their submissions would be welcomed for consideration. The topic diversity of the submissions we received, though, might have been either enhanced or hindered by the fact that, throughout most of the year 2020 and the initial weeks of 2021, several major global developments were occurring as these chapters were being curated, written, reviewed, rewritten, copyedited, structured, and compiled. The global COVID-19 pandemic was devastating numerous human populations around the planet, disrupting an incalculable number of lives and forcing numerous changes in how members of our species, including our contributors and their stakeholders, interacted with one another, whether in our homes, schools, communities, or workplaces, at social gatherings, and, of course, online. In addition to affecting our social discourse, the pandemic has also caused major economic disruptions, as widespread lockdowns and business closures meant significant adjustments for people in societies worldwide, worsened by the chaotic or non-existent distribution of vaccines. And, the world's richest but most unequal economy, the U.S., experienced both a major recession and a significantly contentious set of national and state elections, as well as a major upwelling of both political unrest and conflict and social justice-related events and responses, all of which had significant both national and international implications. Through all of this chaos and tumult, our contributors persevered and delivered an array of interviews and essays that offer a wide range of perspectives, experiences, concepts, and practices that we think readers will appreciate, consider, and employ in their own faculty personal sustainability plans and actions, at home, at work, at play, and on the way. In organizing these submissions, we identified several broad themes and have grouped them accordingly.

\section{HOW THIS BOOK IS ORGANIZED}

In our call for proposal submissions, we asked our faculty colleagues to consider their personal sustainability practices related to the 17 United Nations Sustainable Development Goals (SDGs), which set tangible social, environmental, and economic goals that, according to many world experts, need to 
Table 1.1 United Nations Sustainable Development Goals (UN SDGs)

\begin{tabular}{l|l}
\hline Goal no. & Goal description \\
\hline 1 & End poverty in all its forms everywhere \\
\hline 2 & End hunger, achieve food security and improved nutrition and promote sustainable agriculture \\
\hline 3 & Ensure healthy lives and promote well-being for all at all ages \\
\hline 4 & $\begin{array}{l}\text { Ensure inclusive and equitable quality education and promote lifelong learning opportunities } \\
\text { for all }\end{array}$ \\
\hline 6 & Achieve gender equality and empower all women and girls \\
\hline 7 & Ensure availability and sustainable management of water and sanitation for all \\
\hline 8 & Ensure access to affordable, reliable, sustainable, and modern energy for all \\
\hline 9 & $\begin{array}{l}\text { Promote sustained, inclusive, and sustainable economic growth, full and productive employment } \\
\text { and decent work for all }\end{array}$ \\
\hline 10 & $\begin{array}{l}\text { Build resilient infrastructure, promote inclusive and sustainable industrialization, and foster } \\
\text { innovation }\end{array}$ \\
\hline 11 & Reduce inequality within and among countries \\
\hline 12 & Make cities and human settlements inclusive, safe, resilient, and sustainable \\
\hline 13 & Ensure sustainable consumption and production patterns \\
\hline 14 & Take urgent action to combat climate change and its impacts \\
\hline 15 & $\begin{array}{l}\text { Protect, restore, and promote sustainable use of terrestrial ecosystems, sustainably manage } \\
\text { forests, combat desertification, and halt and reverse land degradation and halt biodiversity loss }\end{array}$ \\
\hline 5 & $\begin{array}{l}\text { Strengthen the means of implementation and revitalize the global partnership for sustainable } \\
\text { development }\end{array}$ \\
\hline 17 & and and inclusive societies for sustainable development, provide access to justice \\
\hline 15 &
\end{tabular}

Source: U.N. Department of Economic and Social Affairs, 2020.

be met by the year 2030 in the areas of climate action, poverty, hunger, infrastructure, health, and other pressing global issues (see Table 1.1). The United Nations calls on individuals, organizations, and governments to act together, globally and locally, to address these serious concerns. The urgency for each of us to act is even more necessary as the COVID-19 pandemic impacts, usually negatively, all of the 17 SDGs (UN/DESA, 2020).

This volume comprises essays and interviews by 36 authors representing 25 institutions, seven countries (United States, United Kingdom, Austria, Germany, France, Australia, and Romania), and at least six disciplines (Management, Economics, Finance, Physics, Biology, and Fine Arts). Each manuscript was evaluated following a double-blind peer observation and review process and revised at least twice. The result is a collection of diverse perspectives and inspiring insights on the authors' personal sustainability 
practices. We applaud the authors' accomplishments and continuous efforts; we are humbled by their trust in us and in this project, as the authors agreed to open up and share their personal sustainability plans, successes, failures, and frustrations. Finally, since the United Nations Sustainable Development Goals serve as one of the overarching themes for this book, we matched how each of the authors' practices may contribute to advancing one or more of the U.N. SDGs (see Table 1.2).

The book is divided into four parts. In Part I: Sustainability Practices in Action, the authors describe and reflect on how systems thinking contributes to sustainability actions for a more sustainable world. Robert Sroufe summarizes his personal sustainability activities, especially those related to buildings, using the ABCD (Awareness, Baseline Understanding, Creative Solutions, and Down to Action) planning process and offers insights on how his students and other stakeholders can scale their respective efforts more quickly and systematically than otherwise. Bernadette Roche argues that faculty need to adopt a teacher-scholar-practitioner action-oriented identity and aspire to have broader influence in multiple systems. Jimmy Y. Jia and Rick Dickinson introduce a methodology that highlights how an action in one subsystem impacts and ripples through adjacent subsystems. Kevin D. Carlson and John H. Grant develop a model tied to the UN SDGs to guide business college (and their students') transition towards sustainable development actions. Finally, Billy Friebele offers a practical application on how he merges sustainability practices with his artistic creations. We are grateful to Billy for allowing us to feature a photo of his sculpture, entitled "Disposable Empires", as the cover of our book.

In Part II: Internal/External Integration (Values to Action), the authors discuss opportunities and challenges as they attempt to leverage and connect their own personal sustainability values, visions, and beliefs to their sustainability practices, with the goal of transforming their respective households, organizations, communities, classrooms, and institutions. Shelley F. Mitchell interviews Paul Shrivastava to understand how personal sustainability values and actions inform his various leadership roles in academia, including his current position as Chief Sustainability Officer at Pennsylvania State University and his leadership in the Academy of Management as the lead co-founder of its Organizations and the Natural Environment (O.N.E.) division. Amy K. Townsend reflects on the need for both inner (values) and outer (action) dimensions of multiple personal sustainability practices over decades, both within and outside of sustainability-related organizations. Ralph Meima shares his professional and personal sustainability journey, while questioning whether current managerial teaching and tools can adequately address sustainability crises. Bruce Paton relates his experience with public service and challenges his students (and our readers) to "think like a city" when developing 

Table $1.2 \quad$ Authors' contributions to the United Nations Sustainable
Development Goals

\begin{tabular}{|c|c|c|}
\hline Author/s & Summary & UN SDGs \\
\hline \multicolumn{3}{|c|}{ Part I: Sustainability Practices in Action } \\
\hline Sroufe & $\begin{array}{l}\text { Application of ABCD (Awareness, Baseline, Create } \\
\text { a Vision, and Down to Action) planning methodology } \\
\text { to scale efforts and more quickly implement sustainable } \\
\text { solutions. }\end{array}$ & $\begin{array}{l}7,9,11 \\
12,13\end{array}$ \\
\hline Roche & $\begin{array}{l}\text { Reflection on why faculty should adopt a teacher-scholar- } \\
\text { practitioner identity and aspire to have broader influence } \\
\text { including impacts on public and cultural spheres. }\end{array}$ & $\begin{array}{l}1-17, \text { in } \\
\text { general }\end{array}$ \\
\hline Jia \& Dickinson & $\begin{array}{l}\text { Presentation of a methodology to evaluate how mitigating } \\
\text { actions taken in one subsystem can impact and ripple } \\
\text { through adjacent subsystems. }\end{array}$ & $7,12,13$ \\
\hline Carlson \& Grant & $\begin{array}{l}\text { Application of a proposed model framework ("spinning } \\
\text { top") to describe business college transition and progress } \\
\text { towards sustainability linked to achievement of the UN } \\
\text { SDGs. }\end{array}$ & $\begin{array}{l}1-17, \text { in } \\
\text { general }\end{array}$ \\
\hline Friebele & Merging sustainability practices with artistic creation. & $\begin{array}{l}9,11,12 \\
13,14,15 \\
17\end{array}$ \\
\hline \multicolumn{3}{|c|}{ Part II: Internal and External Integration (Values to Action) } \\
\hline Mitchell & $\begin{array}{l}\text { Interview with Paul Shrivastava and his journey building } \\
\text { institutional capacity for sustainability. }\end{array}$ & $\begin{array}{l}1-17, \text { in } \\
\text { general }\end{array}$ \\
\hline Townsend & $\begin{array}{l}\text { Reflection on the balance between doing sustainability } \\
\text { (outer world) and being sustainable (inner world). }\end{array}$ & $\begin{array}{l}7,12,13 \\
15,16\end{array}$ \\
\hline Meima & $\begin{array}{l}\text { Evaluation of the limits of sustainability-oriented education } \\
\text { and research in meeting climate change goals and proposal } \\
\text { of practical ideas for managers to effectively address } \\
\text { sustainability challenges. }\end{array}$ & $7,8,13$ \\
\hline Paton & $\begin{array}{l}\text { Discussion on how to leverage personal civic activism and } \\
\text { public service to explain key challenges and changes in } \\
\text { achieving sustainability. }\end{array}$ & $1,7,13,17$ \\
\hline Stone & $\begin{array}{l}\text { Reflection on teaching sustainability values and how to } \\
\text { model personal sustainability behaviors to students. }\end{array}$ & $\begin{array}{l}3,7,8,12, \\
13\end{array}$ \\
\hline Miller & $\begin{array}{l}\text { Reflection on how building a sustainable cabin for personal } \\
\text { use provided teaching insights on the tradeoffs between } \\
\text { beauty, interconnectedness, and utility provided by nature. }\end{array}$ & $\begin{array}{l}6,7,9,11 \\
12,15\end{array}$ \\
\hline \multicolumn{3}{|c|}{ Part III: Curriculum Development in Sustainability Education } \\
\hline Edwards \& Stubbs & $\begin{array}{l}\text { Creating space for Earth System talk by walking a radically } \\
\text { reflexive path in sustainability education curricula. }\end{array}$ & $\begin{array}{l}1,2,5,6,7 \\
12,13,16\end{array}$ \\
\hline
\end{tabular}




\begin{tabular}{|c|c|c|}
\hline Author/s & Summary & UN SDGs \\
\hline Heuer & $\begin{array}{l}\text { Discussion of reasons why teaching and research in business } \\
\text { ethics require risk taking and innovative theories and } \\
\text { strategies. }\end{array}$ & $\begin{array}{l}7,12,13 \\
14,16\end{array}$ \\
\hline $\begin{array}{l}\text { Cocke, Gentsch, Hefley, \& } \\
\text { Reichert }\end{array}$ & $\begin{array}{l}\text { Development of a new (undergraduate) course with a focus } \\
\text { on the UN SDGs. }\end{array}$ & $\begin{array}{l}1-17, \text { in } \\
\text { general }\end{array}$ \\
\hline Nelson \& Ionescu & $\begin{array}{l}\text { Discussion of a course development with a focus on changes } \\
\text { and adaptation in response to the climate crisis. }\end{array}$ & 12,13 \\
\hline \multicolumn{3}{|c|}{ Part IV: Faculty Personal Sustainability as Social Movement } \\
\hline Kanashiro & $\begin{array}{l}\text { Interview with Jessica Thomas and her leadership founding } \\
\text { a network of over 2,000 scholars engaged in leveraging the } \\
\text { power of business for good. }\end{array}$ & $\begin{array}{l}8,10,11 \\
12,17\end{array}$ \\
\hline $\begin{array}{l}\text { Obara, Klangboonkrong, } \\
\text { Chapman, \& Frank }\end{array}$ & $\begin{array}{l}\text { Reflection on the role of educators as key drivers in } \\
\text { changing paradigms in the pursuit of a more sustainable } \\
\text { future. }\end{array}$ & $\begin{array}{l}1-17, \text { in } \\
\text { general }\end{array}$ \\
\hline $\begin{array}{l}\text { Delmestri, Etchanchu, } \\
\text { Bothello, Habersang, Huerter } \\
\text { O, \& Schüßler }\end{array}$ & $\begin{array}{l}\text { Launching of a new social movement "Organization } \\
\text { Scientists for Future" (OS4Future) comprised of } \\
\text { management scholars who seek to act on the climate } \\
\text { emergency. }\end{array}$ & $11,12,13$ \\
\hline Venkatesan & $\begin{array}{l}\text { Discussion of how sustainability has shaped the author's } \\
\text { role in teaching economics and civic activism, including } \\
\text { the founding of a non-profit organization focused on } \\
\text { sustainability education and grassroot activism. }\end{array}$ & $\begin{array}{l}6,12,13 \\
14\end{array}$ \\
\hline
\end{tabular}

sustainability solutions. Thomas E. Stone suggests that valuing one's time is the most important action related to sustainability that we can instill in our students and describes how he models his personal choices (including not owning a smartphone) to describe the concept and importance of time in the classroom. Van V. Miller walks us through the building process of his backwoods cabin to explain how his sustainability endeavors are anchored in three main concepts: beauty, interconnectedness, and utility, contrasting conservation and preservation.

Part III: Curriculum Development in Sustainability Education provides reflections and examples on how authors developed new curricula around topics related to the UN SDGs. Melissa Edwards and Wendy Stubbs advance a radically reflexive approach calling for holistic and systemic views that challenge and question assumptions and values. Similarly, Mark Heuer challenges faculty members to step outside an institutionalized mindset that rewards incremental reactive advances and urges colleagues to be more proactive and take greater risks in business ethics research, teaching, and service. The following two sets of authors offer practical suggestions and examples of curriculum development. Gary Cocke, Joanna Gentsch, William E. Hefley, and 
Carolyn Reichert describe a new course that covers the breadth and the interrelationships among the UN SDGs and report that students felt energized and engaged to act on their learnings. Dave Nelson and George Ionescu explain how to integrate course design, processes, and outcomes to teach corporate social responsibility.

Finally, Part IV: Faculty Personal Sustainability as Social Movement reflects on how faculty can launch, join, and/or lead social movements to advance sustainability goals. Patricia Kanashiro, one of this volume's co-editors, interviews Jessica Thomas, a co-founder of B Academics, a network of faculty interested in understanding how businesses can be a force for good and how she encourages interactions between B Corps and her sustainable entrepreneurship students. Louise Obara, Te Klangboonkrong, Gary Chapman, and Regina Frank reflect on the role of educators leading the development of sustainability policies and practices. Giuseppe Delmestri, Helen Etchanchu, Joel Bothello, Stefanie Habersang, Gabriela Gutierrez Huerter O, and Elke Schüßler report on their initiative founding of Organization Scientists for Future (OS4Future), a worldwide movement of scholars who seek to act on the climate emergency. Finally, Madhavi Venkatesan describes her experience as an academic economist teaching sustainability and as a founder of a non-profit organization focused on sustainability education and grassroots activism.

\section{OBSERVATIONS, AND LESSONS LEARNED}

The co-editors believe our contributors have provided a significant impetus regarding why we sustainability faculty need to walk our talk and how we might consider doing so more substantively, frequently, and effectively. We were heartened and inspired by the fact that so many of our colleagues were engaged in such a wide variety of personal sustainability practices and were apparently very effective in their efforts. We have identified several future opportunities that were not fully developed in this volume, and which were likely not emphasized enough in our initial call for contributions. First, most of our authors and interviewees focused primarily on environmental sustainability, with a few notable exceptions, and either did not mention or did not focus on socio-economic sustainability, in particular UN SDGs \#1 (no poverty), \#2 (no hunger), \#3 (good health and well-being), \#4 (quality education), and \#5 (gender equality). In addition to environmental sustainability, we encourage greater attention to socio-economic issues, such as immigration, racial and gender equity, and wealth and income gaps.

Second, several concepts that are often associated with sustainability did not seem to receive as much attention as we expected in our contributors' chapters, though there were several much-appreciated contributor exceptions. Those topics included personal health, spirituality, biodiversity, permaculture, polit- 
ical involvement, voluntarism, and numerous aspects of management (including leadership, planning, information and measurement systems, policy, circular economy, supply chain, and investment). The co-editors take responsibility for not emphasizing these important sustainability aspects sufficiently in the call, and we hope to signal to readers that much more could be explored on the overall theme of this volume than we were able to include within it.

Third, sustainability in developing countries present their own opportunities and challenges, especially focused on socio-economic problems (Jamali \& Keram, 2016), which was admittedly not the focus of this volume. The reasons why developing country faculty personal sustainability practices likely diverge from those in developed countries vary from restricted access to resources (e.g., personal vehicles, larger homes, mega stores, natural resources) to limited access to opportunities, such as travel and free time. Nonetheless, full-time academics in developing countries often command at least middle-class incomes, allowing some to adopt middle-class and sustainable consumption patterns, regarding personal vehicles, homes, and home appliances and furnishings.

So, what did the co-editors learn during this project that we want to share with our readers? First, we learned that walking the sustainability talk is a popular topic among sustainability academics and that many of our colleagues are at least privately (and some publicly) asking how consistent they are in practicing what they are preaching about sustainability. Second, we were heartened to know that so many of us are actively engaged in a wide range of sustainability practices, from micro to macro levels of action and discourse (Starik \& Kanashiro, 2020).

Third, we are aware that any of several barriers may exist regarding why some faculty are hesitant to share their personal sustainability values and actions with their stakeholders, including their students. These hindrances may include a significant sense of humility about sharing personal information of any kind (i.e., what is "personal" is "private" for some of our colleagues), or a feeling that faculty are not expert or confident enough to share their personal sustainability practices with others. These are understandable potential obstacles but also create "out-of-site, out-of-mind" problems, so faculty are advised to begin with a moderate approach to the topic, so that they share some of their personal sustainability perspectives with some of their stakeholders, to the extent that both faculty members and their stakeholders feel comfortable regarding the selected sustainability topics, amount, intensity, and frequency of that sharing.

Finally, we sensed that most of us have a long way to go to be as consistent as we think we should be in walking our sustainability talk and that many of us are interested in sharing our experiences on that topic, all with the hope that, 
in the words of the new U.S. President Joe Biden, "we'll lead, not merely by the example of our power, but by the power of our example" (Biden, 2021).

\section{NOTE}

1. We were deeply inspired by the following words of noted Brazilian teacher and philosopher, Paulo Freire: "I cannot be a teacher without exposing who I am. Without revealing, either reluctantly, or with simplicity, the way I relate to the world, how I think politically. I cannot escape being evaluated by the students, and the way they evaluate me is of significance for my modus operandi as a teacher. As a consequence, one of my major preoccupations is the approximation between what I say and what I do, between what I seem to be and what I am actually becoming" (Freire, 1996, p. 87).

\section{REFERENCES}

Bergart, A.M. \& Simon, S.R. (2004). Practicing what we preach: Creating groups for ourselves. Social Work with Groups, 27(4): 17-30.

Biden, J. (2021). Inaugural Address by President Joseph R. Biden, Jr. [transcript]. The White House, January 21, at https://www.whitehouse.gov/briefing-room/speeches -remarks/2021/01/20/inaugural-address-by-president-joseph-r-biden-jr/ (accessed May 22, 2021).

Ciers, J., Mandic, A., Toth, L.D., \& Veld, G.O. (2019). Carbon footprint of academic air travel: A case study in Switzerland. Sustainability, 11(1): 80, https://doi.org/10 $.3390 /$ su11010080.

Freire, P. (1996). Pedagogy of freedom: Ethics, democracy, and civic courage. Lanham, M.D.: Rowman \& Littlefield.

Grandelis, M. \& Davis, D. (2018) Being the change: A new kind of climate documentary. Gabriola, B.C.: New Society Publishers.

Haraway, D. (2016). Staying with the trouble: Making kin in the Chthulucene. Durham, N.C.: Duke University Press.

Jamali, D. \& Karam, C. (2016). Corporate social responsibility in developing countries as an emerging field of study. International Journal of Management Review, 20(1): 32-61, https://doi.org/10.1111/ijmr.12112.

Kanashiro, P., Rands, G., \& Starik, M. (2020). Walking the sustainability talk: If not us, who? If not now, when? Journal of Management Education, https://doi.org/10 $.1177 / 1052562920937423$.

McKenzie-Mohr, D. (2011). Fostering sustainable behavior: An introduction to community-based social marketing. Gabriola, B.C.: New Society Publishers.

Mihai, A. (2014). Seven things teachers preach but fail to practise. The Educationalist, November 11, at https://educationalist.eu/seven-things-teachers-preach-but-fail-to -practise-9cb71 f0d56c8 2) (accessed May 22, 2021).

myclimate (2020). At http://www.myclimate.org (accessed September 1, 2020).

Parodi, O., \& Tamm, K. (Eds.) (2019). Personal sustainability: Exploring the far side of sustainable development. Abingdon: Routledge.

Ruff, T. (2019). When teachers don't practice what they preach. Lion's Roar, at https:// www.lionsroar.com/when-teachers-dont-practice-what-they-preach/ (accessed August 2, 2020). 
Schwartz, N. (2008). Ed Begley, Bill Nye wage friendly eco-war. ABC News, July 10, at https://abcnews.go.com/Technology/story?id=5353371\&page=1 (accessed January 28, 2021).

Starik, M. \& Kanashiro, P. (2020). Advancing a multi-level sustainability management theory. In Wasieleski, D.M. \& Weber, J. (Eds.), Sustainability (Business \& Society 360, Vol. 4). Bingley: Emerald Publishing, 17-42, https://doi.org/10.1108/S2514 -175920200000004003 .

Swennen, A., Lunenberg, M., \& Korthagen, F. (2008). Preach what you teach! Teacher educators and congruent teaching. Teachers and Teaching: Theory and Practice, 14(5-6): 531-542, https://doi.org/10.1080/13540600802571387.

UN/DESA United Nations Department of Economic and Social Affairs (2020). UN/ DESA Policy Brief \#81: Impact of COVID-19 on SDG Progress: A statistical perspective, August 27, at https://www.un.org/development/desa/dpad/publication/un -desa-policy-brief-81-impact-of-covid-19-on-sdg-progress-a-statistical-perspective/ (accessed January 27, 2021).

Wallace-Wells, D. (2020). The uninhabitable Earth: Life after warming. New York, N.Y.: Tim Duggan Books. 